\title{
FANCF Gene
}

National Cancer Institute

\section{Source}

National Cancer Institute. FANCF Gene. NCI Thesaurus. Code C86553.

This gene may be involved in the regulation of DNA repair. 